\title{
Pengembangan Pariwisata Kawasan Gede Bage Berbasis Ekowisata
}

\author{
Lia Afriza, Anti Riyanti, dan Septy Indrianty \\ STIEPAR YAPARI AKTRIPA Bandung \\ lia.afriza@gmail.com, anti.ryantik@gmail.com, Septy_indrianty@yahoo.com
}

\begin{abstract}
Bandung provides a variety of tourist attractions, such as culinary arts, theme parks, and shopping destination. The city is developed into a city of technology or technopolis which is located in the southern part region, called Gede Bage. Thus, to maintain the natural environment in the technology-based development area, the city also encouraging eco-tourism activities. Hence, the purpose of this study is to identify the concept of eco-tourism in accommodating the impact of technopolis development. The approach adopted in this study was comprehensive policy analysis approach that examined the norms imposed in developing the city and tourism. The norms consist of regulation, strategies, planning documents, law and other related policies. The results show that the existing facilities at technopolis area are potentials to be developed as eco-tourism attraction. Furthermore, competent human resources have played as an important role to succeed the Bandung Technopolis area as eco-tourism attraction.
\end{abstract}

Keywords-eco-tourism; technopolis; city

\section{Pendahuluan}

Perkembangan pariwisata Kota Bandung pada tahun 2015 mencapai 5 juta wisatawan dengan 500 ribu wisatawan mancanegara, (Keny, Kabid Disbudpar; Kompas.com 18/2/16). Pemkot menargetkan wisatawan tahun 2016 sebanyak 5,6 juta baik domestik maupun mancanegara dengan branding "Wonderful Indonesia". Branding tersebut diharapkan kecantikan Indonesia (alam dan masyarakatnya) dapat dinikmati oleh wisatawan dari berbagai belahan dunia. Target 1 juta wisatawan mancanegara di Kota Bandung adalah sebagai salah satu dukungan dalam pengembangkan pariwisata. Berdasarkan data tersebut dapat berdampak pada pendapatan Kota Bandung yang direalisasi sebesar 6 triliun pada pertengahan tahun 2016, dengan kontribusi sebesar 2,5\% dari pendapatan devisa Indonesia.

Berdasarkan Rencana Tata Ruang Wilayah (RTRW) Kota Bandung 2011-2031 Kecamataan Gede Bage seluas 980 hektar dan Rancasari seluas 955 hektar, ditetapkan sebagai sub wilayah kota SKW (Satuan Kawasan Wilayah) Gede Bage. Pada SKW Gede Bage diperuntukan untuk perkantoran pemerintahan, ruang terbuka hijau, pemukiman, pesawahan, perdagangan dan jasa, serta rencana pembangunan teknopolis dengan luas 800 hektar di Kecamatan Gede Bage. (Info Bandung)

Dalam penyusunan kegiatan pembagian wilayah idealnya satu wilayah harus memiliki $30-40 \%$ ruang terbuka yang bisa dimanfaatkan untuk daerah hijau. Ruang hijau itu dapat dimanfaatkan untuk kegiatan yang berkaitan dengan pariwisata berbasis konservasi atau penghijauan lingkungan. Perencanaan kegiatankegiatan wisata yang bisa dilakukan di kawasan Gede Bage, diantaranya; Teknopolis/ Sumarecon, Danau Terapung, Budaya dan Pelestarian Burung Blekok, Danau Kubah, dan Gelora Bandung Lautan Api.

Penelitian ini untuk meningkatkan kualitas dan kuantitas Daya Tarik Wisata di kawasan Gede Bage dalam wilayah Dinas Kebudayaan dan Pariwisata Kota Bandung diharapkan menghasilkan produk diversifikasi yang dimiliki oleh Kota Bandung. Penelitian ini menganalisis daya tarik yang ada di sekitar kawasan Gede Bage Bandung, memberikan rekomendasi tentang pengembangan kawasan Gede Bage serta merekomendasi kegiatankegiatan apa yang harus dilakukan serta siapa yang harus mengerjakannya. Sehingga manfaatnya adalah sebagai pijakan dalam pengembangan pariwisata di Kota Bandung juga sebagai pedoman penyusunan program dan kegiatan dalam rencana kerja di Dinas Pariwisata dan Kebudayaan serta lintas sektor lain yang berkaitan dengan pengembangan di kawasan Gede Bage Kota Bandung.

Dalam menyusun kajian pengembangan kawasan wisata Gede Bage, pengkajiannya tidak terlepas dari elemen/komponen perencanaan komprehensif yang bersifat fisik maupun non fisik, yaitu:

1. Kondisi pengembangan pariwisata Kota Bandung

2. Gambaran umum kawasan Gede Bage

3. Analisis potensi dan pasar

4. Analisis pengembangan pariwisata berbasis ekowisata 
5. Arahan program dan pengembangan kawasan Gede Bage

RPJM (Rencana Pembangunan Jangka Panjang dan Menengah) Jawa Barat 2013-2018 merupakan pembangunan secara menyeluruh dalam rangka penyiapan kemandirian masyarakat Jawa Barat. Dengan misi, diantaranya:

1. Mewujudkan Jawa Barat yang nyaman dan Pembangunan Infrastruktur Strategis yang berkelanjutan.

2. Meningkatkan kualitas sosial, seni budaya, peran Pemuda dan Olah Raga, serta Pengembangan Pariwisata dalam Bingkai Kearifan Lokal.

James J. Spillane (1987) dalam Budi (2013) menjelaskan lima unsur penting dalam industri pariwisata, yang disingkat menjadi FAITH, yaitu:

1. Facilities (fasilitas-fasilitas yang diperlukan): bangunan, hotel, restoran, toko souvenir dan fasilitas buatan manusia lainnya yang dirancang untuk menarik para pengunjung.

2. Attraction (daya tarik): sungai, danau, pegunungan, pantai, dll yang memiliki keindahan dan mampu menarik para pengunjung untuk datang.

3. Infrastructure (Infrastruktur): listrik, telekomunikasi, jalan, air minum untuk mendukung kebutuhan hotel, restoran, pertokoan dan pelayanan usaha wisata lainnya.

4. Transportation (transportasi): sarana untuk mempermudah aksesibilitas wisatawan, seperti kereta, bus, dll.

5. Hospitality (keramahtamahan): iklim politik, budaya lokal, keamanan, dst yang membuat para pengunjung merasa nyaman dan menyenangkan.

Hal ini sejalan dengan pemikiran Middleton (2002), destinasi merupakan salah satu industri yang membentuk lima sektor travel and tourism. Kepariwisataan merupakan suatu kesatuan utuh yang tidak dapat berdiri sendiri. Keterkaitan tersebut membuat sebuah sistem kepariwisataan. Maka tidak mengherankan bahwa sistem kepariwisataan akan membentuk sebuah rantai ekonomi (multiflier effect).

Suatu lokasi wisata dapat menarik untuk dikunjungi oleh wisatawan harus memenuhi syarat-syarat untuk pengembangan daerahnya. Menurut Fandeli (1995), syarat-syarat tersebut adalah:

1. Something to see, artinya objek wisata tersebut harus mempunyai sesuatu yang bisa dilihat atau dijadikan tontonan oleh pengunjung wisata. Dengan kata lain objek tersebut harus mempunyai daya tarik khusus yang mampu untuk menarik minat dari wisatawan untuk berkunjung di objek tersebut.

2. Something to do, artinya agar wisatawan bisa melakukan sesuatu yang berguna untuk memberikan perasaan senang, bahagia, relax, berupa fasilitas rekreasi baik itu arena bermain ataupun tempat makan terutama makanan khas dari tempat tersebut sehingga mampu membuat wisatawan lebih betah untuk tinggal di tempat itu.

3. Something to buy, artinya di tempat tujuan wisata harus tersedia fasilitas untuk berbelanja (shopping) terutama barang souvenir dan kerajinan rakyat sebagai oleholeh untuk dibawa pulang ke tempat asal

Konsep pariwisata perkotaan ada 6 yaitu tourist historic city, cultural city, resort city, fantasy city, creative city dan urban ecotourism. Konsep terakhir merupakan pariwisata perkotaan yang berwawasan lingkungan. Prinsip pengembangan kawasan yang memungkinkan untuk diterapkan dalam pengembangan di kawasan Gede Bage adalah prinsip yang berbasis Ekowisata. Kawasan Gede Bage memiliki potensi untuk dikembangkan sebagai kota teknopolis, kegiatan dan atraksi diantaranya: Danau Gede Bage sebagai serapan air yang dimanfaatkan untuk rekreasi, Pusat Stasiun Monorel Jawa Barat, stadion olah raga, dan wisata perkotaan (Sumarecon). Salah satu cara untuk mengindari kemacetan, mengurangi polusi dan membuka pintu keluar sebagai penghubung ke kota lain, maka akan dibuka dua pintu tol di kawasan Gede Bage.

Adapun, prinsip ekowisata berdasarkan Konferensi Internasional tentang Urban Ecotourism (2004) tersebut dapat diperjelas sebagai berikut:

\section{Prinsip Konservasi}

Pengembangan ekowisata harus mampu memelihara, melindungi dan atau berkontribusi untuk memperbaiki sumber daya alam. Memiliki kepedulian, tanggung jawab dan komitmen terhadap pelestarian lingkungan alam dan budaya, melaksanakan kaidah-kaidah usaha yang bertanggung jawab dan ekonomi berkelanjutan. Prinsip konservasi terdiri dari 2 elemen yaitu konservasi alam dan konservasi budaya.

\section{Prinsip Partisipasi Masyarakat}

Pengembangan harus didasarkan atas musyawarah dan persetujuan masyarakat setempat, peka dan menghormati nilai-nilai sosial budaya serta tradisi keagamaan yang dianut masyarakat setempat di sekitar kawasan. 
3. Prinsip Ekonomi

Pengembangan ekowisata harus mampu memberikan manfaat untuk masyarakat setempat dan menjadi penggerak pembangunan ekonomi.

\section{Prinsip Edukasi}

Pengembangan

ekowisata harus mengandung unsur pendidikan untuk mengubah sikap atau perilaku seseorang menjadi memiliki kepedulian, tanggung jawab dan komitmen terhadap pelestarian lingkungan. Pengembangan ekowisata juga harus meningkatkan kesadaran dan apresiasi terhadap alam, nilai-nilai peninggalan sejarah dan budaya, serta memberikan nilai tambah dan pengetahuan bagi pengunjung, masyarakat dan para pihak yang terkait.

\section{Prinsip Wisata}

Pengembangan ekowisata harus dapat memberikan kepuasan pengalaman kepada pengunjung untuk memastikan usaha ekowisata dapat berkelanjutan. Selain itu pengembangan ekowisata juga harus mampu menciptakan rasa aman, nyaman dan memberikan kepuasan serta menambah pengalaman bagi pengunjung.

WWF Indonesia mengemukakan Konsep dasar eco sendiri meliputi; nature based, ecologically, suitainable, environmentaly, educative, locally benefit, general tourism satisfaction. Konsep tersebut adalah:

\section{Nature based (Berbasis alam)}

Pengembangan ekowisata (ecotourism) didasarkan pada lingkungan alam dengan fokus pada lingkungan biologi, fisik dan budaya.

\section{Ecologically suitainable (Berkelanjutan} secara ekologis)

Ecotourism dapat memberikan acuan terhadap pariwisata secara keseluruhan dan dapat membuat ekologi yang berkesinambungan.

\section{Environmentally educative (Pendidikan lingkungan) \\ Pengembangan ekowisata harus} mengandung unsur pendidikan atau perilaku seseorang menjadi memiliki kepedulian, tanggung jawab dan komitmen terhadap pelestarian lingkungan.

4. Locally beneficial (Manfaat bagi masyarakat lokal)

Pengembangan ecotourism harus dapat menciptakan keuntungan yang nyata bagi masyarakat sekitar. Pengembangan harus didasarkan atas musyawarah dan persetujuan masyarakat setempat, peka dan menghormati nilai-nilai sosial budaya dan tradisi keagamaan yang dianut masyarakat di sekitar kawasan.
5. Generates tourist satisfaction

(Menghasilkan kepuasan wisatawan)

Pengembangan ekowisata harus mampu memberikan kepuasan pengalaman kepada pengunjung untuk memastikan usaha ekowisata dapat berkelanjutan

\section{Metode Penelitian}

Dalam penelitian ini dibuat kerangka penelitian yang digunakan sebagai dasar atau patokan dalam melakukan penelitian. Kerangka penelitian dibuat sebagai berikut:

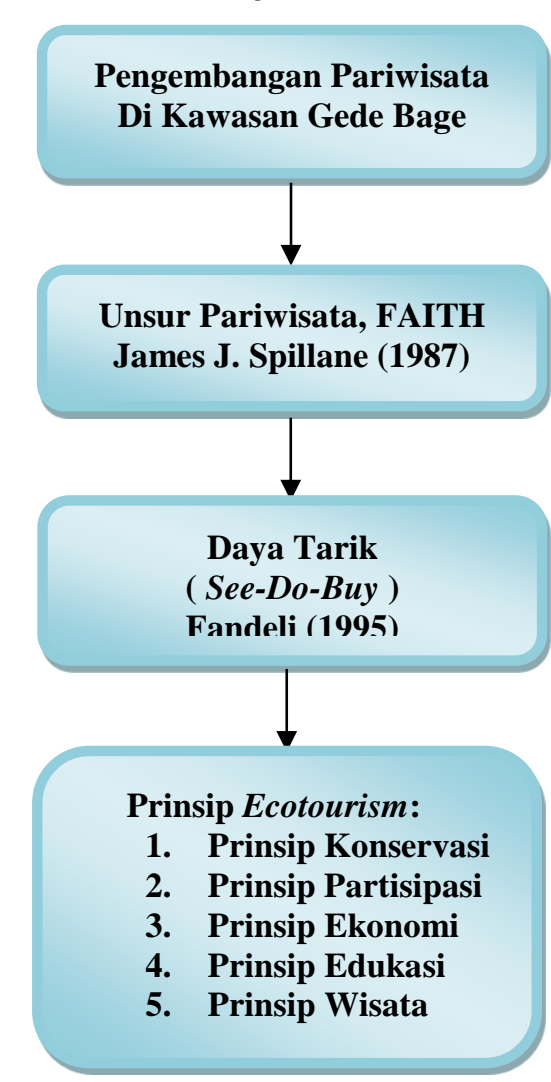

Sumber: Data Olahan Peneliti, 2016

GAMBAR 1. KERANGKA PENELITIAN

Metode yang digunakan pada penelitian ini adalah metode deskriptif. Menurut Sugiyono (2011:54) penelitian deskriptif yaitu penelitian yang dilakukan untuk membuat perbandingan atau menghubungkan dengan variabel lain. (Nazir, 2005:54), metode deskriptif adalah suatu metode dalam meneliti status sekelompok manusia, suatu obyek, suatu set kondisi, suatu sistem pemikiran, ataupun suatu kelas peristiwa pada masa sekarang. Tujuan dari penelitian deskriptif ini adalah untuk membuat deskripsi, gambaran atau lukisan secara sistematis mengenai pengembangan kawasan wisata Gede Bage berbasis ekowisata. 
Penelitian ini menggunakan metode deskriptif serta menggunakan metode wawancara sebagai teknik pengumpulan data di lapangan dengan hasil penelitian. Desain penelitian adalah metode survey dengan jenis explanatory survey. Data penelitian yang dikumpulkan kemudian diolah dan dianalisis, adalah:

\section{Data Primer}

Data yang diperoleh langsung dari objek penelitian melalui wawancara, observasi dan dokumentasi. Data primer akan diperoleh dari masyarakat Kota Bandung khususnya sekitar Gede Bage.

\section{Data Sekunder}

Data yang diperoleh dari sumber-sumber lain yang menunjang penelitian ini, seperti kebijakan tertulis. Kemudian data sekunder akan diperoleh dari orang kedua atau pihak lain dalam hal ini bisa berbentuk informasi dari berbagai pihak terkait yang dapat membantu dalam melengkapi data penelitian ini.

Adapun pengumpulan data dalam penelitian ini menggunakan:

\section{Observasi}

Observasi yang digunakan dalam penulisan ini adalah observasi langsung dengan maksud melakukan pengamatan terhadap segala proses yang terjadi secara langsung di lapangan.

\section{Wawancara (Interview)}

Jenis data diperoleh dalam penelitian melalui wawancara (interview), menurut pendapat ahli "wawancara adalah suatu cara pengumpulan data yang digunakan untuk memperoleh informasi langsung dari sumbernya. Wawancara ini digunakan bila ingin mengetahui hal-hal dari responden secara lebih mendalam serta jumlah responden sedikit" (Sugiyono, 2012:105).

\section{Studi Dokumentasi}

Satori (2011:149) menyatakan bahwa studi dokumentasi yaitu "mengumpulkan dokumen dan data-data yang diperlukan dalam permasalahan penulisan lalu ditelaah secara intens sehingga dapat mendukung dan menambah kepercayaan serta pembuktian suatu kejadian".

Dengan teknik studi dokumentasi ini, penulis dapat memperoleh informasi bukan dari orang sebagai narasumber, tetapi dari berbagai sumber tertulis atau dari dokumen yang ada pada informan. Manfaat lain dari studi dokumentasi adalah untuk melengkapi hasil observasi atau wawancara, sehingga hasil tersebut akan lebih kredibel atau dapat dipercaya dengan dukungan dari dokumendokumen yang terkait dengan fokus penelitian.
Dalam penelitian ini pengumpulan data dilakukan melalui kajian literature terhadap dokumen-dokumen tertulis seperti penelitian sebelumnya, peraturan, buku teks, situs internet, surat kabar, foto dan bahan-bahan tertulis lainnya yang relevan dengan topik penelitian.

\section{HASil PENELITIAN DAN PEMBAHASAN}

Sebelum artikel dimasukkan ke dalam Hasil dari penelitian berdasarkan data yang telah didapatkan dari lapangan, yaitu data dari hasil observasi, interview dan dokumentasi serta studi literature sebagai data pendukung. Pembahasan ini akan fokus pada lima cakupan bahasan yaitu mengenai kondisi pengembangan pariwisata Kota Bandung, gambaran umum kawasan Gede Bage, analisis potensi dan pasar, analisis pengembangan pariwisata berbasis ekowisata, arahan program dan pengembangan kawasan Gede Bage. Hasil penelitian ini akan dibahas lebih jelas dan mendalam pada penjelasan di bawah ini.

\section{A. Kondisi Pengembangan Pariwisata Kota Bandung}

Untuk memperoleh kepuasan dalam perjalanan wisatanya, dibutuhkan pengetahuan bagi pengelola kota tentang prinsip pengembangan pariwisata khususnya di daerah Kota Bandung, diantaranya:

1. Ramah lingkungan

2. Keberlanjutan kehidupan masyarakat perkotaan

3. Peningkatan kesejahteraan warga kota

4. Sinergitas antar institusi terkait

5. Terpeliharanya heritage kota

6. Terjaganya keseimbangan sumber daya alam

7. Peningkatan kualitas prasarana dan sarana perkotaan

8. Terpeliharanya kearifan lokal

9. Kualitas dan diversikasi produk pariwisata

10. Kepuasan pengunjung/wisatawan

Namun kebijakan pemerintah dalam penempatan leading sector pengembangan kawasan Gede Bage belum ada. Tentunya hal ini menjadikan dana PIPPK juga belum ada yang mengarahkan. Informasi RIPDA yang belum tersosialisasikan secara merata di kalangan dinas maupun masyarakat. Tema yang diusung dalam pengembangan kawasan Gede Bage sesuai dengan RIPDA dalam Perda 2013 yang ditetapkan adalah kawasan olah raga tetapi sesuai dengan pertumbuhan, juga berkembang tema ada perubahan menjadi teknopolis. Untuk memperlancarkan pengembangan kawasan ini sebaiknya Perda harus dikomunikasikan dengan baik sehingga semua dinas dan masyarakat bisa mendukung tujuan Gede Bage sebagai kawasan wisata. Sebagai contoh Perda 2009/2011 yang 
menyangkut mengenai acara kesenian sunda dan sosio kultural.

Konsep pengembangan fasilitas wisata memperjelas fungsi kota yang semakin berkembang dapat dilihat pada contoh kasus di Kota Bandung yaitu fungsi pemerintahan dan perkantoran, fungsi jasa perdagangan, fungsi industri, fungsi jasa, fungsi pendidikan, fungsi wisata; terutama wisata kota (urban tourism), fungsi penelitian dan pengembangan serta fungsi jasa kesehatan. Berdasarkan fungsi tersebut, pengembangan kawasan wisata Kota Bandung terbagi menjadi kawasan Wisata Gegerkalong - Setiabudi, kawasan Wisata Sukajadi - Sarijadi - Setra Sari - Pasteur, kawasan Wisata Cihampelas - Cipaganti, kawasan Wisata Alun-alun-Sudirman-OtistaGardujati- Pasirkaliki, kawasan Wisata Dago Utara - Punclut, kawasan Wisata Gedung Sate Gasibu - Sabuga, kawasan Wisata Padasuka Suci, kawasan Wisata Ir. H. Juanda - Merdeka - Riau, kawasan Wisata Braga - Asia Afrika Cikapundung, kawasan Wisata Gatot Subroto Binong Jati, kawasan Wisata Tegalega, kawasan Wisata Cibaduyut, kawasan Wisata Gede Bage

Kawasan di atas merupakan kawasan yang dikembangkan di Kota Bandung untuk memperkaya daya tarik dan memiliki tema yang berbeda kemenarikanya. Semua ini diciptakan untuk memperluas dan menganekaragamkan produk wisata yang dimiliki oleh Kota Bandung. Kawasan yang akan menambah daya tarik baru dan memiliki tema yang berbeda dari apa yang dimiliki oleh Kota Bandung adalah kawasan Gede Bage sebagai kota teknopolis dengan didukung oleh beberapa daya tarik yang akan memperkuat kemenarikan di kawasan tersebut.

\section{B. Gambaran Umum Kawasan Gede Bage}

Berdasarkan RTRW Kota Bandung 20112031, Kecamatan Gede Bage seluas 980 ha dan Rancasari seluas 955 ha ditetapkan sebagai Sub Wilayah Kota (SWK) Gede Bage. Dalam RTRW tersebut, SWK Gede Bage diperuntukan untuk perkantoran, pemerintahan, ruang terbuka hijau, pemukiman, pesawahan, perdagangan dan jasa. Atas fakta-fakta di atas, rencana pembangunan kawasan teknopolis hanya seluas 800 ha di Kecamatan Gede Bage yang memiliki 979,3 ha karena atas dasar keseimbangan pembangunan. Gede Bage sebuah kawasan di Bandung Timur yang dulu sepertinya tidak diperhitungkan. Bertahun-tahun kawasan ini lebih dikenal sebagai area persawahan juga tidak sedikit yang sebagian menjadi lahan tidur. Daerah yang dekat dengan kawasan Cibiru dan Sapan ini lebih dikenal sebagai daerah yang sering menjadi langganan banjir jika musim penghujan. Selain itu kawasan Gede Bage dikenal sebagai terminal peti kemas, pasar induk
Gede Bage, dan sekarang ini dikenal juga lokasi stadion Gelora Bandung Lautan Api (GBLA).

Tata kota Kecamatan Gede Bage sebelumnya adalah mix land use yang pemetaan wilayahnya bercampur-campur. Saat wilayah tersebut masih merupakan daerah langganan banjir. Menurut RTRW Kota Bandung tahun 2015-2031 akan membangun pusat kota baru untuk meratakan penyebaran penduduk. Rencana pembangunan pusat kota tersebut adalah Gede Bage yang nantinya akan ada fasilitas skala kota seperti alun-alun, masjid kota, kampus, gedung pemerintahan, sekolah dan lainnya. Salah satunya adalah membangun tempat rekreasi. Rencana tersebut juga membuat kota dengan banyak danau resapan dalam upaya menanggulangi banjir musiman yang selalu melanda kecamatan ini. Dengan perencanaan massal, pemerintah mengharapkan agar kota baru ini menarik banyak investor dan juga penduduk muda baru yang produktif untuk bekerja ataupun membuka usaha. Dalam hal ini di kawasan Gede bage diharapkan ada tim kreatif untuk mencapai rencana ini.

Untuk menjadi penyeimbang lingkungan kota yang padat diperlukan tempat wisata sebagai sarana rekreasi masyarakat. Tidak terlepas dari ciri khas Bandung dengan wisata alamnya, kawasan Gede Bage ini akan menciptakan danau-danau resapannya menjadi tempat wisata alam yang indah dan terpadu.

\section{Analisis Potensi Dan Pasar}

Pengembangan kawasan Gede Bage sebagai kota teknopolis dijadikan peluang oleh kota Bandung sebagai potensi wisata yang memiliki tema berbeda seperti yang ada di Kota Bandung. Dalam mempersiapkan kawasan Gede Bage ini pemerintah sudah mulai membangun fasilitas dan daya tarik penunjang lainnya untuk menjadikan Gede Bage sebagai kota mandiri. Potensi wisata yang sudah berkembang di kawasan Gede Bage sekarang diantaranya:

\section{UMKM (Usaha Mikro Kecil Mandiri)}

Gede Bage memiliki 594 UKM, 162 industri makanan dan 12 industri kerajinan. UKM ini merupakan potensi yang bisa dijadikan satu rangkaian kegiatan dari wisata. Industri kerajinan hasilnya bisa dijadikan cindera mata dan proses pembuatan kerajinan bisa dijadikan sebagai salah satu atraksi yang dapat dilihat atau pengunjung dapat ikut serta melihat proses pembuatan kerajinan tersebut. Industri kerajinan tangan yang terkenal seperti tas rajutan yang berada di Rancanumpang Gede Bage RW 07 / RT 05 merupakan salah satu industri kerajinan yang dicari ketika wisatawan berkunjung ke kawasan Gede Bage, selain itu ada juga industri rumahan dalam membuat makanan yang 
terkenal bahkan menjadi brand Kota Bandung, yaitu brownies Amanda yang berada di kawasan Gede Bage Kecamatan Rancasari Kampung Rancabolang. Brownies Amanda menjadi salah satu produk yang diminati wisatawan berkunjung ke Kota Bandung, bahkan kepopuleran brownies Amanda tersebut sudah tersebar ke seluruh pelosok Indonesia. Untuk UMKM, wilayah yang berada di timur Kota Bandung ini memiliki beberapa program unggulan yang langsung berada dibawah binaan Kecamatan Gede Bage. Program tersebut diantaranya: pengrajin boneka, sistik jamur, sumpiah, pais kurucuk, cobek cau manggala, opor jantung cau manggala dan telor asin. Kecamatan Gede Bage pun memiliki beberapa program yang telah dan tengah berjalan, diantaranya: Program PIPPK Kelurahan; Pengalihan Makam dari Rancabolang ke Rancacili; Desain Kampung Blekok; Ojek Makanan Balita (Omaba); dan Pembentukan Kelurahan Sadar Hukum sebagai dua program tambahan. Selain itu, terdapat juga rumah singgah di Cisaranten RW 11. Rumah singgah tersebut digunakan sebagai pusat informasi budaya dan UMKM di wilayah Gede Bage.

2. Pelestarian Habitat burung Blekok di kampung Ranca Bayawak.

Pembangunan yang akan dilakukan di kawasan ini adalah Kampung Wisata Blekok sebagai wisata unggulan bertema alam di Gede Bage yang masih memelihara habitat lingkungan tempat berdiamnya kumpulan burung yang berjumlah 1500 - 2000 burung blekok yang ada di kumpulan pohon bambu. Habitat burung ini unik, pergi dan pulang ke tempat tersebut. Paginya jam 6 dan akan pulang jam 3 sore kembali lagi ke kumpulan pohon bambu. Ini merupakan atraksi yang akan menarik wisatawan jika kelestariannya tetap terpelihara dengan baik, sehingga bisa mendukung pengembangan Gede Bage berbasis ekowisata. Untuk meningkatkan kualitas pengunjung, kampung wisata ini menambah atraksinya dengan memelihara budaya dan seni pertunjukan yang dimiliki bahkan, sekarang menciptakan tarian burung blekok. Untuk kebutuhan makanan, kawasan ini memiliki keunikan dengan makanan khas desa tersebut seperti telor asin dan pencok pisang batu yang bisa dinikmati di kampung tersebut bahkan bisa dijadikan cindera mata untuk dibawa pulang

3. Wisata olah raga dan fasilitas pendukung

Stadion sebagai salah satu daya tarik bertaraf Internasional yang berdiri megah di Kecamatan Gede Bage, yakni Gelora Bandung Lautan Api (GBLA) menjadi salah satu potensi tujuan wisata di Kecamatan Gede Bage. Seiring dengan laju pembangunan ke depan, Kecamatan Gede Bage akan menjadi daya tarik tersendiri. Wisata olah raga adalah kegiatan yang dilakukan dengan melakukan aktivitas olah raga yang menyenangkan, umumnya dilakukan di kawasan objek wisata.

Berdasarkan hal tersebut terlihat bahwa pariwisata olah raga itu ditujukan kepada suatu kunjungan orang yang bertujuan untuk melihat atau menyaksikan suatu pesta olah raga di suatu tempat atau negara tertentu, dan ikut berpartisipasi dalam kegiatan olah raga itu sendiri.

4. Wisata budaya dan seni

Di beberapa kelurahan sudah mulai menggalakan sanggar-sanggar seni lokal. Seni dan budaya yang ada adalah seni budaya sunda yang harus dijaga kelestariannya. Salah satu pelestarian tersebut yaitu dengan memperkenalkan dan memberikan pelatihan seni kepada kaum muda atau Tarka dari kelurahan tersebut. Pada kawasan Gede Bage terdapat beberapa sanggar seni dan kegiatan yang merupakan produk wisata, bisa dijadikan seni pertunjukan di kawasan Gede Bage juga ditunjang dengan tumbuhnya sanggar-sanggar seni di beberapa kelurahan. Seni yang ada di kawasan Gede Bage adalah calung, reog, singa depok, degung, jaipong dan kacapi suling serta seni yang berkaitan dengan olah raga yaitu purangon silat

Pengembangan kawasan Gede Bage dalam perencanaan sesuai dengan RPJM 2011-2013 direncanakan kawasan ini akan membangun daya tarik utama dan pendukung lain, yaitu:

1. Daya tarik utama adalah pengembangan kota teknopolis yang akan dibangun oleh sumarecon seluas 800 ha di Kecamatan Gede Bage yaitu mengembangan kota mandiri yang berbasis IT dimana diharapkan untuk kawasan ini dapat melakukan kegiatan dan memenuhi kebutuhannya di tempat tersebut tidak meninggalkan wilayah untuk berkantor, bersekolah melakukan kegiatan bisnis dan keperluan bersosialisasi seperti hiburan, olah raga, beribadah dilakukan di kawasan tersebut. Kota sebagai teknopolis dapat dijadikan suatu daya tarik dimana wisatawan dapat melakukan interaksi melihat atau menikmati kehidupan langsung dari bagian kota yang memiliki kebutuhan, dipenuhi di daerah rumah tinggalnya dan tidak harus keluar dari kawasan yang selama ini jika ke daerah Gede Bage, akan melihat kepadatan lalu lintas dikarenakan penduduk setempat harus pergi meninggalkan kawasan.

2. Rekreasi danau sebagai danau resapan seluas 10 ha untuk menanggulangi banjir kawasan Gede Bage. Dalam perencanaan akan membangun fasilitas berupa restoran, 
laboratorium, ruang parkir dan arena jogging track yang mengelilingi danau resapan. Aktifitas yang bisa dilakukan dalam danau terapung selain melihat pemandangan sekitar danau bisa juga dilakukan kegiatan jalan sehat (jogging track) untuk kebugaran, sedangkan di danaunya sendiri bisa dilakukan beberapa kegiatan yang menunjang dalam wisata danau, kegiatan yang bisa dilakukan salah satunya adalah berperahu atau beberapa kegiatan yang berkaitan dari pemanfaatan danau tersebut. Dalam perencanaan danau yang ada adalah sebagai resapan air dikala musim penghujan dan air tersebut bisa dimanfaatkan sebagai penyimpanan sumber air untuk dikonsumsi (PDAM) dan disalurkan ke warga dengan proses recycling sesuai dengan aturan yang ada dan kelayakan apabila akan dikonsumsi oleh masyarakat. Kegiatan sekitar danau akan ditambah fasilitas taman sehingga memberikan juga tambahan atraksi bagi pengunjung untuk arena rekreasi dan meningkatkan kualitas hidup bagi pengunjung serta membantu pemerintah dalam menghijaukan suatu wilayah.

3. Mesjid Terapung, mesjid yang dirancang berdiri di atas lahan 11 hektare, di tepi danau buatan yang berfungsi sebagai kolam retensi pencegah banjir seluas 10 hektare. Masjid itu sendiri akan dibangun seluas 1 - 2,5 hektar. Namanya adalah Al-Jabbar, salah satu fasilitas yang dipersiapkan oleh pemerintah untuk kelengkapan dalam pengembangan kawasan Gede Bage sebagai kota teknopolis. Mesjid ini selain untuk beribadah juga merupakan tempat belajar bagi orang sekitar tentang kegiatan beragama. Sesuai dengan fasilitas yang akan dibangun di dalam mesjid yaitu perpustakaan, museum, ruang untuk manasik dan tempat pertemuan (seminar).

4. Kawasan Gede Bage teknopolis merupakan kawasan yang terintegrasi sebagai digital valley merupakan pengembangan kawasan berbasis IT dan di sana akan dibangun satu ruangan diperuntukan sebagai pusat latihan wisausaha yang berbasis IT. Dengan kecanggihan teknologi ini, diharapkan semua informasi yang dibutuhkan khususnya mengenai Kota Bandung akan disediakan oleh perusahaan sebesar Twitter, Google, facebook sampai Kaskus, berencana berkantor dan melakukan riset di tempat ini, sehingga dapat diakses oleh masyarakat dan wisatawan

Program tersebut sebagai upaya pemerintah untuk mempersiapkan sumber daya manusia ketika kawasan Gede Bage beralih fungsi yang penduduknya semula bermata pencaharian sebagai penggarap sawah / pertanian lalu mengalami perkembangan menjadi kawasan teknopolis dimana lahan sawah berubah menjadi satu kawasan perumahan, perkantoran disertai fasilitas penunjang yang diperlukan, maka sumber daya manusia telah siap dengan pelatihan yang dilakukan dari sekarang secara bertahap.

Konsep wisata ini mengacu dan berlatar belakang Kota Bandung sendiri dengan kondisi geografinya yang dikelilingi oleh pegunungan sehingga kota ini berada di cekungan. Hal tersebut menjadi dasar konsep perancangan tempat wisata ini yang semua fasilitasnya mengelilingi cekungan (danau). Dengan adanya rencana pembangunan monorel dan jalan tol ini tentu memberikan kemudahan akses ke destinasi, terlebih bila fasilitas pelayanan akomodasi, makan dan minum yang ditawarkan dengan harga yang sesuai. Potensi Daya Tarik Wisata yang disiapkan oleh Dinas Kebudayaan dan Pariwisata harus memiliki sinergisitas antara organisasi pemerintah dan swasta lainnya. Kondisi eksisting daya tarik yang ada di kawasan Gede Bage, adalah di bawah ini:

TABEL 1. KONDISI EKSISTING DAYA TARIK

\begin{tabular}{|c|c|c|c|c|c|}
\hline No & Kecamatan & Daya tarik / atraksi wisata & fasilitas & Lokasi & Keterangan \\
\hline 1 & Gede Bage & $\begin{array}{c}\text { Kampung Wisata } \\
\text { Burung Blekok }\end{array}$ & $\begin{array}{l}\text { 1. Home industri } \\
\text { makanan } \\
\text { 2. Masjid } \\
\text { 3. Aula }\end{array}$ & $\begin{array}{c}\text { Kampung } \\
\text { Ranca } \\
\text { Bayawak }\end{array}$ & $\begin{array}{ll}\text { 1. Jalan menuju ke } \\
\text { kampung masih } \\
\text { minim }\end{array}$ \\
\hline & & GBLA & $\begin{array}{ll}\text { 1. } & \text { Ruang parkir } \\
\text { 2. Ruang } \\
\text { informasi }\end{array}$ & $\begin{array}{l}\text { Di Kampung } \\
\text { Ranca Bolang }\end{array}$ & $\begin{array}{l}\text { 1. Jalan entri / akses } \\
\text { jalan hanya satu } \\
\text { 2. Belum dilalui } \\
\text { angkutan umum } \\
\text { 3. Rambu-rambu } \\
\text { informasi belum } \\
\text { ada }\end{array}$ \\
\hline & & $\begin{array}{l}\text { Pusat kerajinan dan } \\
\text { UMKM (Rajutan, }\end{array}$ & & & $\begin{array}{ll}\text { 1. Home Industri } \\
\text { 2. Informasi tidak } \\
\text { ada }\end{array}$ \\
\hline
\end{tabular}




\begin{tabular}{|c|c|c|c|c|c|}
\hline No & Kecamatan & Daya tarik / atraksi wisata & fasilitas & Lokasi & Keterangan \\
\hline & & $\begin{array}{c}\text { Makanan, Konfeksi/ } \\
\text { maklon) }\end{array}$ & & & \\
\hline \multirow[t]{3}{*}{2} & \begin{tabular}{ll}
\multicolumn{2}{l}{ Ranca Sari } \\
wisata & kuliner \\
dan & wisata \\
belanja & \\
\end{tabular} & Amanda & $\begin{array}{l}\text { 1. Parkir } \\
\text { 2. Musola }\end{array}$ & $\begin{array}{l}\text { Di kawasan } \\
\text { metro }\end{array}$ & \\
\hline & & Metro Mall & $\begin{array}{ll}\text { 1. } & \text { Ruang parkir } \\
\text { 2. } & \text { Mesjid } \\
\text { 3. } & \text { Hotel } \\
\text { 4. } & \text { Pusat informasi } \\
\text { 5. } & \text { Restoran dan } \\
& \text { rumah makan } \\
\end{array}$ & $\begin{array}{l}\text { Di kawasan } \\
\text { metro }\end{array}$ & \\
\hline & & Pengrajin Makanan & Home industri & $\begin{array}{c}\text { Komplek } \\
\text { Riung } \\
\text { Bandung } \\
\end{array}$ & \\
\hline
\end{tabular}

Sumber: Data Olahan Peneliti, 2016

Setelah menganalisis potensi di kawasan Gede Bage, selanjutnya adalah analisis pasar di kawasan tersebut. Seperti yang diketahui bahwa dalam perencanaan destinasi, meliputi identifikasi serangkaian rekomendasi yang terkait dengan pengembangan dan peningkatan kemajuan destinasi, menetapkan skala prioritas terhadap peluang yang ada, mengidentifikasi waktu pekerjaan rencana aksi pengembangan destinasi, termasuk aspek industri yang terkait dengan proses implementasi rencana yang ada pada tabel 1.

Pengembangan destinasi tersebut dengan meningkatkan kondisi destinasi menjadi lebih baik berdasarkan kepada pendayagunaan asset/sumberdaya pariwisata yang dimiliki destinasi, mengidentifikasi ketidaksesuaian antara penawaran dengan harapan pasar, mengatasi ketidaksesuaian penawaran produk aktual dengan harapan pasarnya melalui kerangka pengelolaan perencanaan destinasi secara strategik

\section{Analisis Pengembangan Pariwisata \\ Berbasis Ekowisata}

Masyarakat di perkotaan menginginkan keberadaan taman kota yang hijau dan nyaman untuk menetralisirkan polusi udara. Oksigen yang dihasilkan dari keberadaan sebuah taman kota dimana di dalamnya memiliki sejumlah pepohonan hijau yang dapat menjadikan kota sejuk.

Dengan mengetahui beberapa faktor yang dapat menghambat pengembangan destinasi di perkotaan maka pada perencanaan suatu kota sebagai satu daerah tujuan wisata harus memperhatikan aspek keberlanjutan. Kerja sama antara Pemkot Bandung, Pemprov Jawa Barat dan Kementerian PU pada pengembangan kawasan Gede bage ini akan menjadikan tempat rekreasi seperti Garden by The Bay di Singapura. Program ini diluncurkan merupakan program berbasis ekowisata, karena disamping untuk mengatasi masalah lingkungan juga dapat menjadi salah satu tempat wisata di wilayah Kota Bandung.

Dengan memperhatikan dampak tersebut maka prinsip pengembangan ekowisata yang memungkinkan untuk diterapkan dalam pengembangan di kawasan Gede Bage dalam menangani dampak teknologi, seperti Danau Gede Bage itu sendiri, yaitu Eco tourism yang terdiri dari Konservasi, partisipasi/ pemberdayaan, ekonomi, edukasi, wisata, berdasarkan prinsip ekowisata Konferensi Internasional tentang Urban Ecotourism (2004):

1. Prinsip konservasi

Terdiri dari 2 elemen yaitu konservasi alam dan konservasi budaya.

a. Prinsip konservasi alam memiliki kepedulian, tanggung jawab dan komitmen terhadap pelestarian alam serta pembangunan harus mengikuti kaidah ekologis. Kriteria konservasi alam antara lain:

1) Memperhatikan kualitas daya dukung lingkungan kawasan tujuan, melalui zonasi

2) Mengelola jumlah pengunjung, sarana dan fasilitas sesuai dengan daya dukung lingkungan daerah tujuan

3) Meningkatkan kesadaran dan apresiasi para pelaku terhadap lingkungan alam dan budaya

4) Memanfaatkan sumber daya secara lestari dalam penyelenggaraan kegiatan ekowisata

5) Meminimumkan dampak negatif yang timbul dan bersifat ramah lingkungan

6) Mengelola usaha secara sehat

b. Prinsip konservasi budaya, peka dan menghormati nilai-nilai sosial budaya serta tradisi keagamaan masyarakat setempat. Kriteria konservasi budaya antara lain:

1) Menerapkan kode etik ekowisata bagi wisatawan, pengelola dan pelaku usaha ekowisata.

2) Melibatkan masyarakat setempat dan pihak-pihak lainnya (multi stakeholders 
dalam penyusunan kode etik wisatawan, pengelola dan pelaku usaha ekowisata)

3) Melakukan pendekatan, meminta saransaran dan mencari masukan dari tokoh/pemuka masyarakat setempat pada tingkat paling awal sebelum memulai langkah-langkah dalam proses pengembangan ekowisata.

4) Melakukan penelitian dan pengenalan aspek-aspek sosial budaya masyarakat setempat sebagai bagian terpadu dalam proses perencanaan dan pengelolaan ekowisata.

2. Prinsip partisipasi masyarakat. Kriterianya adalah:

a. Melakukan penelitian dan perencanaan terpadu dalam pengembangan ekowisata

b. Membangun hubungan kemitraan dengan masyarakat setempat dalam proses perencanaan dan pengelolaan ekowisata

c. Menggugah prakarsa dan aspirasi masyarakat setempat untuk pengembangan ekowisata

d. Memberi kebebasan kepada masyarakat untuk bisa menerima atau menolak pengembangan ekowisata

e. Membuka kesempatan untuk melakukan dialog dengan seluruh pihak yang terlibat (multi stakeholders) dalam proses perencanaan dan pengelolaan ekowisata

f. Membentuk kerjasama dengan masyarakat setempat untuk melakukan pengawasan dan pencegahan terhadap dilanggarnya peraturan yang berlaku

3. Prinsip ekonomi

Penggerak pembangunan ekonomi, diantaranya:

a. Membuka kesempatan kepada masyarakat setempat untuk membuka usaha ekowisata dan menjadi pelaku-pelaku ekonomi kegiatan ekowisata baik secara aktif maupun pasif.

b. Memberdayakan masyarakat dalam upaya peningkatan usaha ekowisata untuk kesejahteraan penduduk setempat.

c. Meningkatkan ketrampilan masyarakat setempat dalam bidang-bidang yang berkaitan dan menunjang pengembangan ekowisata.

d. Menekan tingkat kebocoran pendapatan (leakage) serendah-rendahnya.

e. Meningkatkan pendapatan masyarakat

f. Membangun yang berimbang (balance development) antara kebutuhan pelestarian lingkungan dan kepentingan semua pihak

4. Prinsip edukasi

Kriteria pengembangan dan produk ekowisata harus: a. Mengoptimalkan keunikan dan kekhasan daerah sebagai daya tarik wisata.

b. Memanfaatkan dan mengoptimalkan pengetahuan tradisional berbasis pelestarian alam dan budaya serta nilai-nilai yang dikandung dalam kehidupan masyarakat sehari-hari sebagai nilai tambah.

c. Mengoptimalkan peran masyarakat sebagai interpreter lokal dari produk ekowisata.

d. Memberikan pengalaman yang berkualitas dan bernilai bagi pengunjung.

e. Dikemas ke dalam bentuk dan teknik penyampaian yang komunikatif dan inovatif

5. Prinsip wisata Kriteria:

a. Mengoptimalkan keunikan dan kekhasan daerah sebagai Daya Tarik Wisata.

b. Membuat Standar Prosedur Operasi (SPO) untuk pelaksanaan kegiatan di lapangan.

c. Menyediakan fasilitas yang memadai sesuai dengan kebutuhan pengunjung, kondisi setempat dan mengoptimalkan kandungan material lokal.

d. Memprioritaskan kebersihan dan kesehatan dalam segala bentuk pelayanan, baik fasilitas maupun jasa.

e. Memberikan kemudahan pelayanan jasa dan informasi yang benar.

f. Memprioritaskan keramahan dalam setiap pelayanan.

Maka jelas dengan destinasi berbasis ekowisata, kawasan ini akan terintegrasi dengan manfaat, sebagai:

1. Wisata

2. Pengendali banjir sekitar Gedebage (Ciwastra, Gede Bage, Rancaekek, Cibiru, Cileunyi) yaitu yang dilalui aliran Sungai Citarum.

3. Sumber air minum

E. Arahan Program Dan Pengembangan Kawasan Gede Bage

Arahan program pengembangan kawasan untuk menghindari kejenuhan saat kunjungan wisatawan adalah melalui:

1. Fasilitas yang semakin komplek minimal sesuai standar. Dalam hal ini kawasan Gede Bage sudah merencanakan fasilitas yang merupakan atraksi buatan manusia yang berbeda dari Daya Tarik Wisata yang lebih cenderung berupa sumber daya. Pada saat ini, fasilitas yang akan dikembangkan di kawasan Gede Bage adalah; pemukiman, restaurant, hotel, konferensi, sekolah, shopping mall, rumah sakit, dll.

2. Atraksi adalah segala sesuatu yang memiliki keunikan, keindahan dan nilai yang berupa keanekaragaman kekayaan alam, budaya dan hasil buatan manusia yang menjadi 
sasaran atau tujuan kunjungan wisatawan. Adapun atraksi yang akan dikembangkan di kawasan Gede Bage adalah wisata belanja, wisata edukasi, wisata taman, dll.

3. Infrastruktural adalah sistem fisik yang menyediakan sarana transportasi serta fasilitas publik lainnya untuk memenuhi kebutuhan dasar manusia, seperti jalan yang akan direncanakan di kawasan Gede Bage menghindari kemacetan lalu lintas di kawasan kota, yaitu dengan membuka dua pintu keluar dan masuk di KM 149 dan Cipularang. Membuka terminal peti kemas pengiriman barang-barang keluar Kota Bandung, membuka jalur monorel yang ada di sekitar Polda menghubungkan BandungJakarta dan Bandung-Cirebon/Tasik.

4. Transportasi adalah atribut akses bagi wisatawan agar dengan mudah dapat mencapai tempat wisata pada sebuah destinasi. Seperti bus Trans Metro, Gedebage stasiun hall, Kereta Cepat, Bus antar kota.

5. Hospitality adalah sikap keramahtamahan yang merupakan perwujudan dari ungkapan someah hade $\mathrm{ka}$ semah, yaitu rasa hormat serta persahabatan kepada wisatawan yang datang ke Bandung

Ada beberapa aspek yang harus diperhatikan untuk mewujudkan hal di atas yaitu dengan meningkatkan kualitas dari pengalaman wisatawan dan kesuksesan destinasi, divalidasi oleh jumlah kunjungan, tingkat hunian dan hasil pendapatan, kemudian rendahnya jumlah kritik terhadap destinasi. Sementara keberlanjutan, intinya pada kemampuan dari suatu destinasi untuk memenuhi pengembangan pariwisata ke depan secara berkelanjutan melalui pertimbangan yang seimbang dalam hal; pemasaran destinasi, pembaharuan produk, mengelola dalam batas kemampuan daya dukung. Arahan pengelolaan (meliputi daya tarik dan pengelolaan pengunjung). Didasarkan pada Kecamatan Gede Bage yang merupakan daerah datar dan hal tersebut sangat berbeda dengan kondisi geografis Bandung umumnya berundak-undak karena berada di daerah pegunungan.

Dalam mencapai rencana kawasan wisata Gede Bage ini terdapat organisasi yang harus terlibat dalam pengembangan destinasi:

1. Pemerintah (government)

Pariwisata berperan penting dalam menunjang perekonomian negara

2. Organisasi Pariwisata Dunia (World Tourism Organization)

Meningkatkan akses masyarakat terhadap pendidikan dan budaya serta meningkatkan standar kesejahteraan masyarakat di dunia, terutama negara miskin dan sedang

3. Organisasi Pariwisata Nasional

Mempromosikan negaranya sebagai destinasi wisata

4. Organisasi Pariwisata Provinsi dan Lokal Mendorong pengembangan ekonomi masyarakat, yaitu Pemerintah Kota harus bisa memelihara asetnya, terutama dalam pengelolaan PKL di kawasan Gede Bage. Di kawasan GBLA sebagai contoh harus dikelola oleh Kompepar (untuk pemberdayaan masyarakat). Sebagai perwakilan dari masyarakat yang ada dalam struktur kecamatan.

Sinergisitas pembangunan pariwisata antar dinas harus ada untuk menunjang target tersebut, dan dapat diimplementasikan pada Program Pembangunan dan Pengembangan kawasan Gede Bage di bawah ini:

Tabel 2. Program Pembangunan dan Pengembangan Kawasan Gede Bage

\begin{tabular}{|c|c|c|c|c|}
\hline No & Prioritas Program & Uraian Program & Jangka Waktu & Stakeholders yang terlibat \\
\hline 1 & $\begin{array}{l}\text { Program-program } \\
\text { yang mengandung } \\
\text { Pelestarian } \\
\text { Lingkungan }\end{array}$ & $\begin{array}{l}\text { 1. Penetapan Kebijakan Konservasi } \\
\text { terhadap lingkungan. } \\
\text { 2. Pengadaan upaya khusus } \\
\text { bangunan lingkungan pelestarian } \\
\text { tertentu yang mengalami } \\
\text { pengalihan fungsi, dengan tetap } \\
\text { mempertahankan struktur } \\
\text { pelestarian. }\end{array}$ & Jangka pendek & $\begin{array}{ll}\text { - } & \text { Bapeda } \\
\text { - } & \text { Dinas Tata ruang dan } \\
\text { cipta karya } \\
\text { - } & \text { Masyarakat }\end{array}$ \\
\hline 2 & $\begin{array}{l}\text { Program-program } \\
\text { Pengembangan } \\
\text { Aktivitas yang } \\
\text { Mengandung Nilai } \\
\text { Edukatif dan Rekreatif }\end{array}$ & $\begin{array}{l}\text { 1. Program berkaitan dengan } \\
\text { produk wisata. } \\
\text { 2. Pengemasan Aktivitas wisata } \\
\text { teknopolis. } \\
\text { 3. Pengemasan dan pembuatan } \\
\text { paket wisata rohani (danau dan } \\
\text { masjid terapung). } \\
\text { 4. Program yang berkaitan dengan } \\
\text { event budaya lokal. }\end{array}$ & Jangka pendek & $\begin{array}{ll}\text { - } & \text { Dinas Pariwisata } \\
\text { - } & \text { ASITA } \\
\text { - } & \text { Institusi Pendidikan } \\
& \text { Pariwisata } \\
\text { - } & \text { Masyarakat }\end{array}$ \\
\hline 3 & $\begin{array}{l}\text { Program-program } \\
\text { yang berkaitan dalam } \\
\text { mengembangkan }\end{array}$ & $\begin{array}{l}\text { Sosialisasi kebutuhan pokok dalam } \\
\text { standar fasilitas dan infrastruktur di } \\
\text { kawasan Gede Bage }\end{array}$ & & $\begin{array}{ll}\text { - } & \text { Perhubungan } \\
\text { - } & \text { PU (ciptakarya dan } \\
& \text { Bina Marga) } \\
\text { - } & \text { PLN }\end{array}$ \\
\hline
\end{tabular}




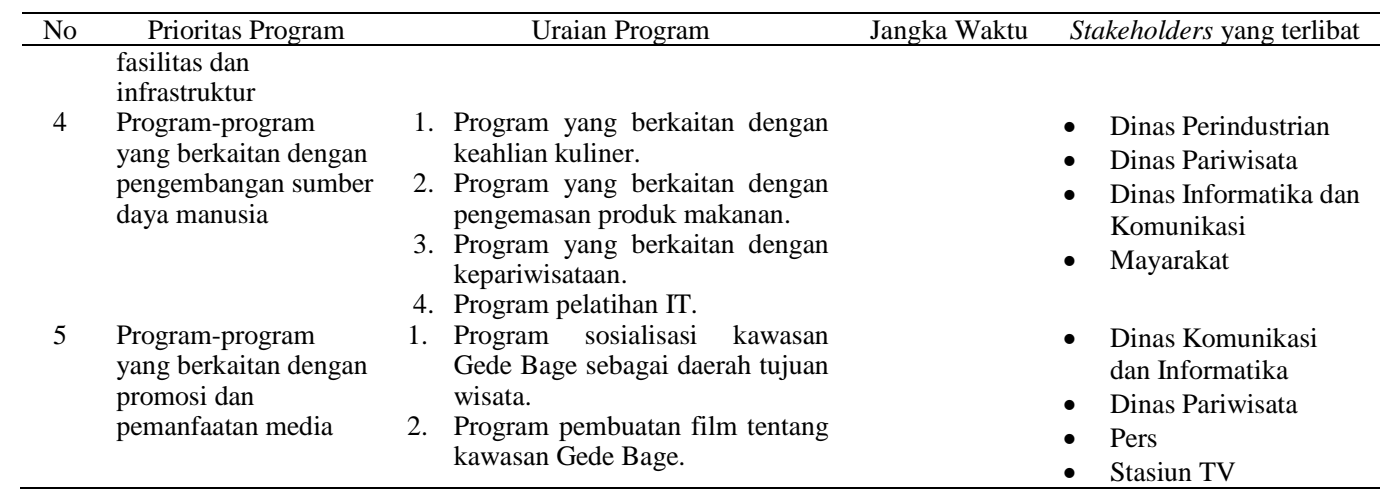

Sumber: Data Olahan Peneliti, 2016

Tabel 3. PerencanaAn Pengembangan Kawasan Gede Bage Sampai 2031

\begin{tabular}{|c|c|c|c|c|c|}
\hline No & Kecamatan & Daya tarik / atraksi wisata & fasilitas & Lokasi & Keterangan \\
\hline \multirow[t]{6}{*}{1} & Gede Bage & $\begin{array}{l}\text { Kawasan Teknopolis } \\
\text { Sumarecon }\end{array}$ & $\begin{array}{l}\text { Site Plan sudah ada } \\
\text { sesuai dgn fasilitas yg } \\
\text { memadai dlm konsep } \\
\text { pembangunan kota } \\
\text { mandiri berbasis IT }\end{array}$ & & $\begin{array}{c}\text { Proses } \\
\text { pembangunan }\end{array}$ \\
\hline & & Danau Serapan & $\begin{array}{l}\text { Site plan sudah ada } \\
\text { dengan fasilitas yg } \\
\text { dipersiapkan sebagai } \\
\text { penunjang menjadi daya } \\
\text { tarik wisata }\end{array}$ & $\begin{array}{c}\text { Kelurahan } \\
\text { Cimincrang }\end{array}$ & $\begin{array}{c}\text { Dalam } \\
\text { perencanaan }\end{array}$ \\
\hline & & Mesjid Terapung & $\begin{array}{l}\text { Site plan sudah ada } \\
\text { dengan fasilitas yg } \\
\text { dipersiapkan sebagai } \\
\text { penunjang menjadi daya } \\
\text { tarik wisata }\end{array}$ & $\begin{array}{l}\text { Kelurahan } \\
\text { Cimincrang }\end{array}$ & $\begin{array}{c}\text { Dalam } \\
\text { perencanaan }\end{array}$ \\
\hline & & $\begin{array}{l}\text { Pusat Perkantoran } \\
\text { Pemerintah }\end{array}$ & $\begin{array}{l}\text { Masih dalam } \\
\text { perencanaan }\end{array}$ & $\begin{array}{l}\text { Tanah Milik } \\
\text { Depag }\end{array}$ & $\begin{array}{l}\text { Dalam proses } \\
2018 \text { baru akan } \\
\text { dilakukan DED }\end{array}$ \\
\hline & & Alun Alun & $\begin{array}{l}\text { Masih dalam } \\
\text { perencanaan }\end{array}$ & & $\begin{array}{c}\text { Dalam } \\
\text { perencanaan }\end{array}$ \\
\hline & & $\begin{array}{l}\text { Gedung Pusat Pelatihan } \\
\text { Digital Valley }\end{array}$ & & $\begin{array}{c}\text { Di dalam } \\
\text { sumarecon } \\
(\text { Google })\end{array}$ & $\begin{array}{c}\text { Dalam } \\
\text { perencanaan }\end{array}$ \\
\hline
\end{tabular}

Sumber: Data Olahan Peneliti, 2016

\section{KESIMPULAN}

Dengan berkembangnya kawasan Gede Bage ini tujuannya agar mampu mengatasi kemacetan di tengah kota dan mengkreatifkan masyarakat untuk membangun wilayah dengan melakukan interaksi dan mengoptimalkan pemanfaatan ruang-ruang untuk kegiatan penduduknya. Sehingga masyarakat dapat berperan untuk menciptakan Daya Tarik Wisata yang ada di Gede Bage dengan berbasis ekowisata. Ruang-ruang ini tidak dikuasai oleh pihak swasta, akan tetapi dinas pertanian akan membangun sebagian lahan menjadi agrowisata.

Berdasarkan hasil penelitian yang telah dilakukan maka dapat dijadikan hal yang terkait pengembangan kawasan Gede Bage, sebagai berikut:

1. Hampir sebagian besar penduduk asli adalah pengarap sawah atau pemilik sawah, sedangkan kawasan Gede Bage akan beralih fungsi maka dimungkinkan akan kehilangan pekerjaan atau mata pencaharian, sehingga pemerintah harus mempersiapkan pelatihan dan pendidikan kepada masyarakat, dimana ketika lahan tergusur penduduk mampu beradaptasi dan mendapatkan pekerjaan baru.

2. Pengembangan kawasan pun akan berdampak pada alih fungsi lahan sehingga ruang hijau yang sebelumnya sangat memadai maka akan beralih fungsi dengan tembok-tembok yang besar mengakibatkan kondisi lingkungan menjadi tidak layak. Maka peran pemerintah untuk dapat tetap menjaga ruang terbuka dan ruang hijau di lingkungan.

3. Perluasan bisnis juga akan berdampak terhadap kemacetan lalu lintas maka diharapkan pemerintah juga akan menyeimbangkan kebutuhan akan infrastruktur agar tidak terjadi kepadatan lalu lintas.

4. Pemanfaatan lahan kosong milik pemerintah untuk dijadikan fasilitas window showing hasil UKM/ kerajinan untuk promosi Gede Bage, sebagai ruang seni budaya daerah, dan 
dibuat ecomuseum dimana ada pameran daur ulang, perpustakaan lingkungan (program adiwiyata) dan berdasarkan Perda No. 9 thn. 2011 pemeliharaan pengembangan bahasa sastra dan aksara sunda bisa dicantumkan pada setiap Daya Tarik Wisata untuk kekhasan.

5. Pemerintah harus lebih mengawasi dan memanfaatkan lahan karena ada tempat yang memerlukan keasrian dan keterjagaan lingkungan dengan pelestarian burung blekok, dikhawatirkan telah beralih fungsi lahan sehingga habitat burung tersebut hilang dari lingkungan atau kawasan Gede Bage dan butuh dilindungi dengan peraturan yang mengikat sehingga pengembang akan tetap mengikuti peraturan tersebut.

6. Program-program wisata harus diperhatikan, dengan dikembangkannya kluster-kluster dan titik-titik wisata sehingga di kawasan Gede Bage ini lengkap terdiri dari wisata eko, wisata olah raga, wisata budaya, wisata pendidikan/edukasi contohnya pengolahan air atau sampah yang bisa dijadikan penelitian siswa. Disamping memperhatikan pengembangan daya tarik yang ada, infrastruktur, juga ada peranan masyarakat yaitu melalui pendekataan seperti ada pelatihan-pelatihan untuk memajukan daerahnya, sarana budaya dan fasilitas pendukung.

7. Dalam pengembangan kawasan Gede Bage diperlukan sinergisitas antar instansi yaitu Disporda yang mengelola GBLA, Dinas Pariwisata yang mengelola Daya Tarik Wisata, Dishub yang menertibkan kawasan dan masyarakat agar kegiatan pembangunan pariwisata dapat berjalan dengan baik.

\section{DAFTAR RUJUKAN}

Ardika, I W. (2003). Pariwisata Budaya Berkelanjutan, Refleksi dan Harapan di Tengah Perkembangan Global. Program Studi Magister (S2): (kajian Pariwisata Program Pasca Sarjana Universitas Udayana)

Budi, A. (2013). Analisis Permintaan Objek Wisata Masjid Agung Semarang. Program Sarjana Fakultas Ekonomika dan Bisnis. Universitas Diponogoro.

Fandeli, C. (2002). Perencanaan Kepariwisataan Alam. Yogyakarta: Liberty.

Gelder, S.V.(2005). Global Brand Strategy. Lond on: Kogan Page

Holloway, J, C, \& Davidson, R. (2009). The Business of Tourism, $8^{\text {th }}$ Edition. England: Pearson Education Limited.

Moh. Nazir. (2005). Metode Penelitian. Bogor: Ghalia Indonesia.
Pike, S. (2008). Destination Marketing; An Integrated Marketing Communication Approach. USA: Elsevier Inc.

Rencana Tata Ruang Wilayah Kota Bandung 2011-2013

Rencana Pembangunan Jangka Panjang dan Menengah Jawa Barat 2013-2018

Richardson, John I \& Martin Fluker. (2004). Understanding and Managing Tourism. person Education Australia, NSW Australia: Australia

Sugiyono. (2011). Metode Penelitian Kuantitatif, kualitatif dan $R \quad \& \quad D$. Bandung: Alfabeta

Undang-undang Nomor. 10 Tahun 2009 Tentang Kepariwisataan.

Undang-undang Nomor.24 tahun 1992

Vanhove, N. (2005). The Economic of Tourism Destination. Great Britain. Elsevier Butterworth-Heinemman

Yani, A. (2011). Pariwisata Perkotaan: Teori dan Konsep.

Rujukan Online:

http://www.seputarbandungraya.com/2016/03/ profil-kecamatan-gedebagedibawah.html? $\mathrm{m}=1$ 